\title{
An Investigation into the Usefulness of Parasites as Tags for Herring (Clupea harengus) Stocks in the Western North Atlantic, with Emphasis on Use of the Larval Nematode Anisakis simplex
}

\author{
Jean F. Chenoweth \\ Maine Department of Marine Resources, Fisheries Research Laboratory \\ West Boothbay Harbor, Maine, USA 04575 \\ Sharon E. McGladdery \\ Department of Fisheries and Oceans, Fisheries Research Branch \\ P. O. Box 5030, Moncton, New Brunswick, Canada E1C 9B6 \\ Carl J. Sindermann \\ National Marine Fisheries Service, Northeast Fisheries Center \\ Woods Hole, Massachusetts, USA 02543 \\ Thomas K. Sawyer \\ National Marine Fisheries Service, Northeast Fisheries Center \\ Oxford, Maryland, USA 21654 \\ and \\ Jeffrey W. Bier \\ Division of Microbiology, Food and Drug Administration \\ Washington, D. C., USA 20204
}

\begin{abstract}
Studies on the prevalence and intensity of selected herring parasites were conducted during 1981-83 in the western North Atlantic. Results are presented on three species of larval nematodes, Anisakis simplex, Hysterothylacium aduncum and Terranova sp., a larval cestode and the fungus, Ichthyophonus hoferi. Of the parasites examined, A. simplex showed the most potential as a natural tag for use in stock discrimination work. Results from this parasite are consistent with results from tagging studies.
\end{abstract}

\section{Introduction}

One of the persistent needs in herring, (Clupea harengus L.) research in the western North Atlantic is a better understanding of stock structure and of seasonal intermixing of stocks. A number of approaches - morphometrics and meristics (Anthony and Boyar, 1968; Parsons, 1975), age and growth (Boyar, MS 1967), tagging (Stobo, MS 1976), biochemistry (Odense and Allen, 1971; Ridgway et al., 1971) and parasites (Boyar and Perkins, 1971) - have provided some insights but questions about stocks and their movements persist.

Of the presently available methods, parasite indicators seem as likely as any to produce low cost and timely information useful in management of herring. Parasites have already proven useful in this role for a number of other fish species such as Pacific sockeye salmon, Oncorhynchus keta (Margolis, 1963), whiting, Merlangius merlangus, (Hislop and MacKenzie, 1976), haddock, Melanogrammus aeglefinus (Lubieniecki,
1977), plaice, Pleuronectes platessa (van Banning et al., MS 1978), cod, Gadus morhua (Sherman and Wise, 1961), and winter flounder, Pseudopleuronectes americanus (Stunkard and Lux, 1965), as well as for Atlantic herring from the North Sea (MacKenzie, MS 1974; Mackenzie and Johnston, MS 1976). The use of parasites as biological tags was explored earlier for herring of the western North Atlantic (Sindermann, 1957). However, since there are some differences in the parasite fauna found in eastern and western North Atlantic herring, since previous studies in the western North Atlantic did not attempt to actually speciate the parasites of greatest potential value, and since these western North Atlantic studies were carried out before significant changes in herring biomass occurred, further examination of parasites as tags seemed relevant.

Previous investigations of herring parasites, which concentrated on larval nematodes inhabiting the body cavity (Sindermann, 1957, 1961; Boyar and Perkins, MS 1971; Parsons and Hodder, 1971; and Lubieniecki, 
1973), indicated that larval Anisakis simplex had the greatest potential for distinguishing between herring populations for the following reasons. They are easily detected by gross examination and, once ensheathed within the herring, can survive as long as their host. They are not subject to seasonal mortality and there is no indication that they affect the survival of the host fish. (Heavy infections were rare, but even these herring seemed healthy at time of capture.) A. simplex is easily identified and distinguished from other nematodes found in the body cavity and is not morphologically altered by freezing. The intermediate hosts involved in the life-cycle (the first intermediate hosts in the Northwest Atlantic are generally euphausiids belonging to the genera Meganyctiphanes and Thysanoessa (Smith, 1983) are known to show fairly stable population dynamics (Kulka et al., 1982).

It was originally decided that the objective of this study should be to assess whether differences in $A$. simplex prevalence (percentage of infected fish per sample) and intensity (mean number of parasites per infected fish) existed between spawning populations off the western Gulf of Maine (i.e. Jeffreys Ledge) and those off Southwest Nova Scotia (Fig. 1). The objective was later expanded to include an attempt to relate concentrations of herring at other than spawning periods to one or the other spawning group, and to include consideration of two other anisakid nematode species, Hysterothylacium aduncum and Terranova sp., Iarval cestodes (Cestoidae: Tetrarhynchidae), and the fungus, Ichthyophonus hoferi, thought to have potential for herring stock separation.

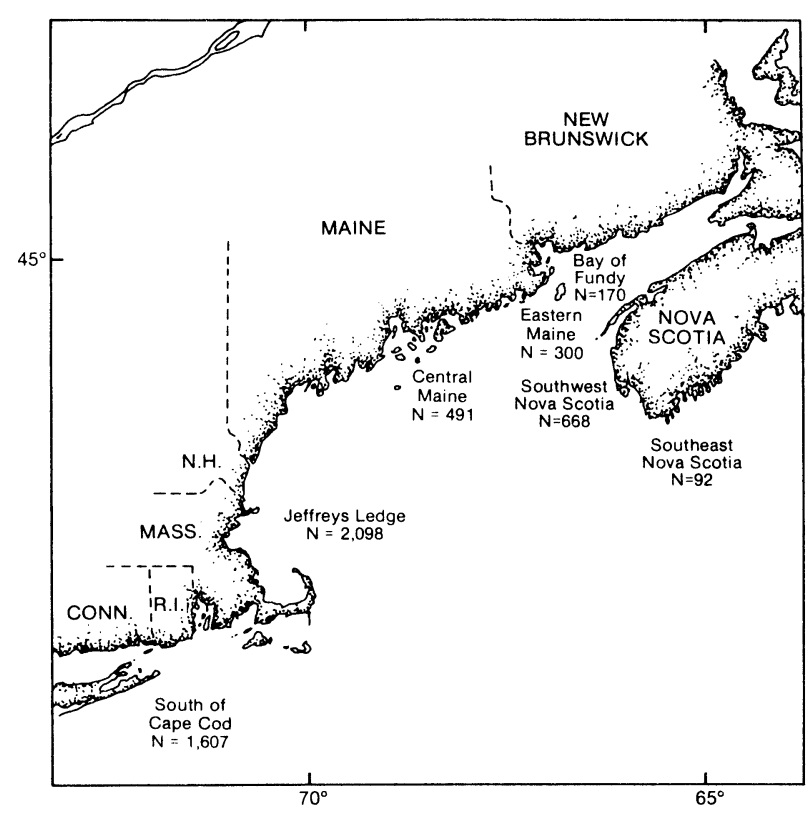

Fig. 1. Herring sampling areas and number of adults (ICNAF maturity stages III-VIII) analyzed from each area, 1981-83.

\section{Materials and Methods}

A total of 6,048 herring was examined for A. simplex, H. aduncum, Terranova sp., larval cestodes and $I$. hoferi. However, prevalence of $A$. simplex in herring has been shown to increase with age and size (Crawford, 1980; Parsons and Hodder, 1971; McGladdery and Burt, 1985). Thus, 622 of the smaller herring from the U.S. coast, those in ICNAF gonadal stages I and II (ICNAF, 1964), were removed from the analysis and only the results from mature fish were compared among areas. (ICNAF gonadal stages $I$ and II are immature herring, III is maturing, IV is almost ripe, $V$ is ripe, $\mathrm{VI}$ is actually spawning, $\mathrm{VII}$ is recently spent, and VIII is resting). The herring excluded were age 1,2 and the smaller specimens of age 3 . The 5,426 fish of maturity stages III-VIII used in the analysis were collected from the locations shown in Fig. 1.

Samples were obtained from commercial catches with the exception of Southeast Nova Scotia samples from Chebucto Head which, along with most of the specimens from areas south of Cape Cod, were obtained from research cruises. Dependence on commercial fisheries for samples placed limitations on sampling design. Herring were frozen prior to examination in most cases but some were examined fresh by the Canadian participant in this study.

Each herring was weighed (gm), measured (total length in $\mathrm{mm}$ ) and sexed, maturity stage was noted, and otoliths were removed for ageing. The body cavity was examined macroscopically for nematode and cestode larvae, which were easily detected in the mesenteries, along the intestine and around the posterior end of the stomach. In addition, the ovaries and epaxial body musculature were candled for any buried larvae. None were found in these locations. Gross examination was made for the external "sandpaper effect" and internally for white nodules on the heart and liver, which are characteristic of infections by I. hoferi.

Methods used by the various participants in checking for fungus, larval cestodes, Terranova sp. and $A$. simplex were identical. However, the Canadian participant used gross and stereo-microscopic examination of the pyloric caeca for $H$. aduncum. This difference in methodology proved to be critical with regard to numbers found and, hence, observations by Canadian and United States participants could not be compared for this species.

The nematode larvae were removed, desheathed, fixed in $70 \%$ ethyl alcohol, and subsequently stored in a mixture of one part glycerine to 10 parts $70 \%$ ethyl alcohol. Specimens used for detailed morphological examination were cleared using glycerine, or lactophenol for larger specimens. Cestode larvae were pre- 
served in the same manner as the nematode larvae by United States participants but were fixed in $5 \%$ formaldehyde and subsequently stored in $70 \%$ ethyl alcohol by the Canadian participant.

\section{Results}

A. simplex and $H$. aduncum were of common occurrence in the specimens examined, and larval cestodes were less frequently found (Table 1). Terranova specimens were rare, and no evidence of infection by the fungus $I$. hoferi was found.

\section{Anisakis simplex}

All Anisakis larvae, without exception, were identical to the type 1 larvae described by Berland (1961). This is now widely recognized as $A$. simplex (Rudolphi, 1809) Dujardin, 1845 (Beverley-Burton and Pippy, 1977). The specimens recovered from the herring examined in this survey were opaque white, usually in a coil and surrounded by host connective tissue. The life cycle of $A$. simplex has been reviewed thoroughly by Oshima (1972), Cheng (1976), and Smith and Wootten (1978). The adult worms mature in the stomach of cetacean hosts and, to a lesser degree, in pinnipeds
(Vik, 1964; Thiel, 1966). Details of the taxonomy of $A$. simplex have been described by Pippy and van Banning (1975), and morphology of larvae by BeverleyBurton and Pippy (1977).

Increases in $A$. simplex prevalence with fish size and age for both Southwest Nova Scotia and Jeffreys Ledge-south of Cape Cod areas (Fig. 2) were consistent with the positive correlations found in previous studies. Fig. 2 is based on the data collected by USA participants (Table 1) and includes observations on immature fish which, as noted above, were excluded from other parts of this study. The data were also examined to see if an increase in prevalence could be detected over a period of 1 year within year-classes. Data from south of Cape Cod were selected for this analysis (Table 2) since five year-classes were represented with adequate numbers of individuals. Every one of the five year-classes showed an increase during the 1 year period. Prevalences at age varied from year to year.

To test for differences in $A$. simplex prevalence and intensity between spawning populations on Jeffreys Ledge and off Southwest Nova Scotia, data for age 6 (1976 year-class) fish caught in late summerearly autumn of 1982 were compared (Table 3 ). Jeffreys Ledge fish showed a prevalence of $16.3 \%$ and a

TABLE 1. Percentage prevalence (P) and intensity (I) of Anisakis simplex, Hysterothylacium aduncum and an unidentified larval cestode in adult herring (maturity stages III-VIII) from various areas, based on examinations by (A) USA and (B) Canadian participants in this study. (" indicated microscopic examination.)

\begin{tabular}{|c|c|c|c|c|c|c|c|c|c|c|}
\hline & \multirow[b]{2}{*}{ Area } & \multirow{2}{*}{$\begin{array}{l}\text { Season } \\
\text { and year }\end{array}$} & \multirow{2}{*}{$\begin{array}{c}\text { Number } \\
\text { of } \\
\text { fish }\end{array}$} & \multirow{2}{*}{$\begin{array}{c}\text { Mean } \\
\text { length } \\
(\mathrm{mm})\end{array}$} & \multicolumn{2}{|c|}{ A. simplex } & \multicolumn{2}{|c|}{ H. aduncum } & \multicolumn{2}{|c|}{$\begin{array}{l}\text { Larval } \\
\text { cestode }\end{array}$} \\
\hline & & & & & $P$ & 1 & $P$ & 1 & $P$ & 1 \\
\hline \multirow[t]{9}{*}{ A. } & S of Cape Cod & Winter 1982 & 1,125 & 306 & 9.4 & 1.3 & 0.1 & 1.0 & 2.9 & 1.7 \\
\hline & & Winter 1983 & 482 & 312 & 8.9 & 1.4 & 0.8 & 1.0 & 4.6 & 2.1 \\
\hline & Jeffreys Ledge & Autumn 1981 & 1,197 & 300 & 8.9 & 1.2 & 0.5 & 1.3 & 2.4 & 1.3 \\
\hline & & Winter 1982 & 461 & 304 & 9.8 & 1.2 & 0.9 & 1.0 & 0.4 & 1.0 \\
\hline & & Autumn 1982 & 440 & 298 & 9.8 & 1.4 & 0.5 & 1.0 & 0.9 & 2.0 \\
\hline & Central Maine & Summer 1982 & 491 & 313 & 6.9 & 2.0 & 0.8 & 1.0 & 1.0 & 1.6 \\
\hline & Eastern Maine & Autumn 1981 & 121 & 289 & 14.9 & 1.8 & 1.7 & 2.0 & - & - \\
\hline & & Autumn 1982 & 179 & 297 & 8.9 & 1.3 & 5.0 & 1.1 & 1.1 & 1.0 \\
\hline & SW Nova Scotia & Autumn 1982 & 408 & 303 & 39.2 & 2.0 & 6.1 & 1.4 & 0.7 & 1.0 \\
\hline \multirow[t]{12}{*}{ B. } & Bay of Fundy & Summer $1981^{\mathrm{a}}$ & 50 & 283 & 18.0 & 1.2 & $62.0^{\star}$ & 1.9 & 2.0 & 1.0 \\
\hline & & Winter $1982^{\mathrm{b}}$ & 20 & 247 & 35.0 & 2.1 & $5.0^{\star}$ & 1.0 & - & - \\
\hline & & Summer $1982^{\mathrm{a}}$ & 60 & 274 & 1.7 & 1.0 & $38.3^{\star}$ & 1.4 & - & - \\
\hline & & Autumn $1983^{a}$ & 40 & 283 & 22.5 & 1.8 & $42.5^{\star}$ & 1.9 & - & - \\
\hline & SW Nova Scotia & Summer $1981^{c}$ & 80 & 292 & 23.8 & 1.5 & $56.3^{\star}$ & 2.4 & - & - \\
\hline & & Winter $1982^{c}$ & 20 & 305 & 45.0 & 1.7 & $25.0^{\star}$ & 1.0 & - & - \\
\hline & & Summer $1982^{d}$ & 20 & 338 & 55.0 & 2.1 & $45.0^{\star}$ & 1.8 & - & - \\
\hline & & Autumn $1982^{c}$ & 80 & 302 & 38.7 & 1.9 & $50.0^{\star}$ & 2.3 & - & 一 \\
\hline & & Summer $1983^{d}$ & 60 & 292 & 36.7 & 2.0 & $51.7^{\star}$ & 2.5 & 2.5 & 1.0 \\
\hline & SE Nova Scotia & Spring $1982^{\circ}$ & 20 & 290 & 20.0 & 1.3 & $25.0^{\star}$ & 1.4 & - & - \\
\hline & & Summer $1982^{\circ}$ & 30 & 310 & 56.7 & 3.0 & $23.3^{*}$ & 1.3 & - & - \\
\hline & & Summer $1983^{\prime}$ & 42 & 268 & 14.3 & 1.3 & $42.5^{\star}$ & 1.9 & - & 一 \\
\hline
\end{tabular}



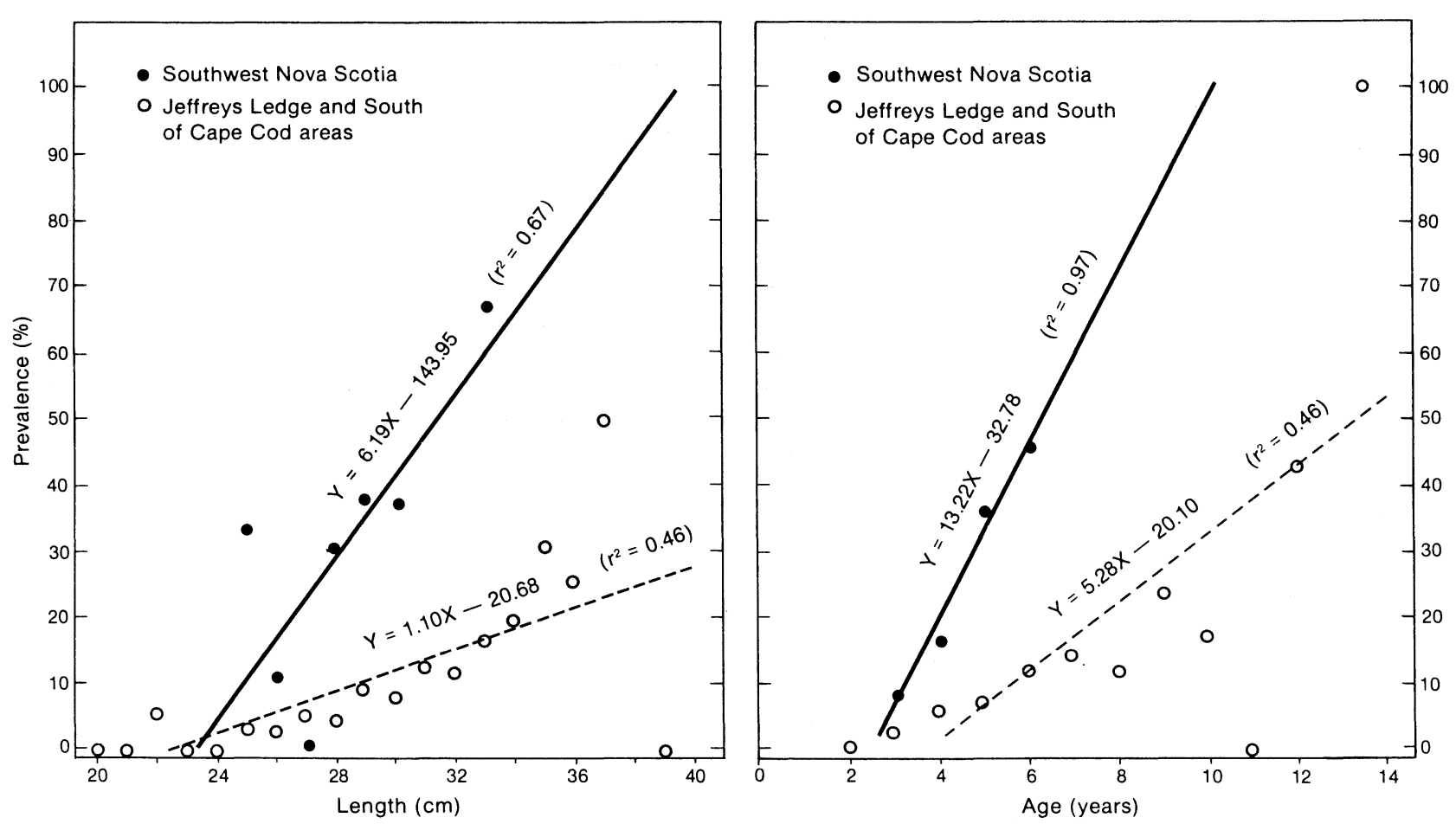

Fig. 2. Relationships between Anisakis simplex prevalence and the length and age of herring from Southwest Nova Scotia in 1982 and the Jeffreys Ledge-South of Cape Cod areas in 1981-83.

TABLE 2. Percent prevalence of Anisakis simplex by year-class and age of herring in the winter 1982 and 1983 samples from the South-of-Cape Cod area. (Number of observations in parentheses.)

\begin{tabular}{lccccc}
\hline \hline \multirow{2}{*}{$\begin{array}{l}\text { Age } \\
\text { (yr) }\end{array}$} & \multicolumn{5}{c}{ Year-class } \\
\cline { 2 - 6 } & 1979 & 1978 & 1977 & 1976 & 1975 \\
\hline 3 & $0.0(24)$ & & & & \\
4 & $3.6(83)$ & $8.6(35)$ & & & \\
5 & & $10.0(20)$ & $5.1(432)$ & & \\
6 & & & $7.0(272)$ & $13.5(289)$ & \\
7 & & & & $14.6(103)$ & $10.5(76)$ \\
8 & & & & & $14.3(14)$ \\
\hline
\end{tabular}

TABLE 3. Prevalence and intensity of Anisakis simplex in age 6 (1976 year-class) herring from two areas during spawning in 1982.

\begin{tabular}{lcc}
\hline \hline Parameter & $\begin{array}{c}\text { Jeffreys } \\
\text { Ledge }\end{array}$ & $\begin{array}{c}\text { SW Nova } \\
\text { Scotia }\end{array}$ \\
\hline Season in 1982 & Sep-Oct & Aug \\
No. of herring & 86 & 300 \\
Mean length $(\mathrm{mm})$ & 319 & 310 \\
Prevalence $(\%)$ & 16.3 & 45.7 \\
Intensity & 1.4 & 2.1 \\
\hline
\end{tabular}

mean intensity of 1.4 , whereas the Southwest Nova Scotia fish showed a prevalence of $45.7 \%$ and a mean intensity of 2.1. This difference in prevalence gave a chi-square value of 23.0 and was significant $(P<0.01)$.
In the widespread seasonal sampling conducted (Table 1), similar clear differences among areas occurred. Prevalences among fish from Southwest Nova Scotia ranged between 23.8 and $55.0 \%$, whereas those from Maine and south ranged from 6.9 to $14.9 \%$. Prevalence in Bay of Fundy was highly variable, ranging between 1.7 and $35.0 \%$. (Bay of Fundy samples were all taken on the New Brunswick side adjacent to the Maine coast.) Southeast Nova Scotia fish, which also showed a wide range in prevalence of 14.3 to $56.7 \%$ had a mean $(29.4 \%)$ within the range of Southwest Nova Scotia fish. Intensity of infestation among Southwest Nova Scotia fish ranged from 1.5 to 2.1, whereas that of fish from Maine and south ranged from 1.2 to 1.4 , except for two samples from central and eastern Maine which had intensities of 2.0 and 1.8 respectively. In the central Maine sample, the high intensity resulted largely from one herring which contained $17 \mathrm{~A}$. simplex. Without this fish, the sample mean intensity was 1.5 , close to that for other southern samples. Bay of Fundy and Southeast Nova Scotia fish showed wide ranges in intensity, as in prevalence, with overall means more similar to those from Maine in the case of the Bay of Fundy (1.4) and to Southwest Nova Scotia in the case of Southeast Nova Scotia (1.9). Thus, the data for prevalence in particular, when combined over the whole sampling period (1981-83) for each major geographic area (Fig. 3) illustrates a marked difference between coastal United States-Bay of Fundy samples and Nova Scotia samples. 


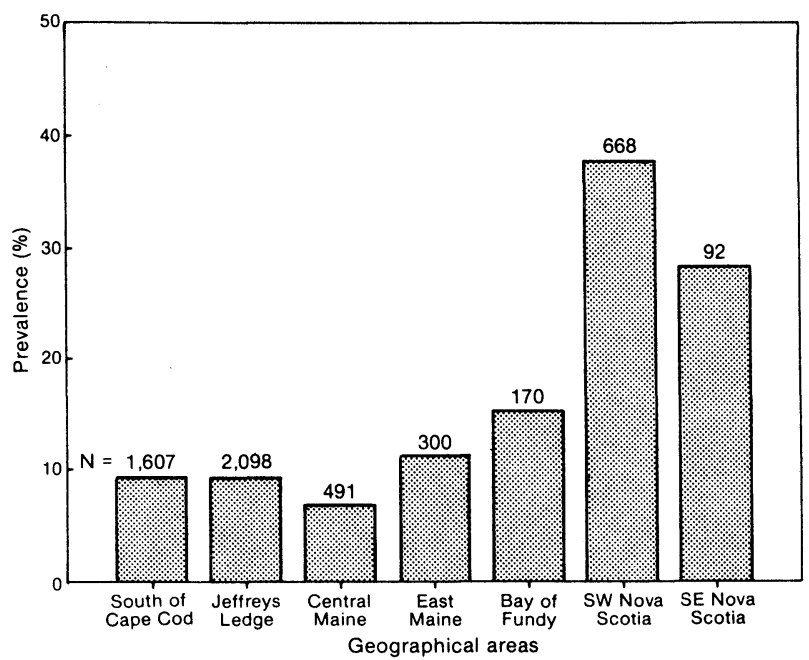

Fig. 3. Prevalence of Anisakis simplex in adult herring (ICNAF maturity stages III-VIII) by geographic areas, 1981-83.

The data do not provide strong evidence for seasonal differences in parasite infection within areas. In samples from Maine and south, seasonal coverage is limited, with almost all samples being taken in autumn and winter. In the Bay of Fundy, lower prevalences occur in summer samples. In Southwest Nova Scotia, both the lowest and highest prevalences occur in summer samples. However, sample sizes were small for most of the Bay of Fundy and Nova Scotia samples, and there was enough variation in mean size of fish sampled (Table 1) to produce substantial differences in prevalence (Fig. 2) and perhaps to obscure seasonal effects. Using the relationship in Fig. 2 to account for differences in mean length of sampled fish indicates that the variation in prevalence of Bay of Fundy fish is not greatly influenced by size. The difference in prevalence in summer Southeast Nova Scotia samples can be accounted for by size, however.

\section{Hysterothylacium aduncum}

Third and fourth stage larvae of $H$. aduncum (Rudolphi, 1802) were found in all size groups of herring, although they were most common in smaller fish. The larvae were most frequently found ensheathed among the pyloric caeca. Descriptive material on $H$. aduncum was reported by Gibson (1983) and McGladdery (MS 1984).

Quantitative analysis could not be done on this nematode species due to the differing methods of examination mentioned above. $H$. aduncum increased in abundance with increasing latitude in data collected by United States participants (Table 1), which agrees with the conclusions for larval nematodes in general reported by Sindermann (1957) and Boyar and Perkins (MS 1971). The Canadian study, using a combination of gross and stereo-microscopic examination, found much higher prevalences (Table 1), with the greater prevalences in smaller fish. The difference in examination methods precludes comparison between the two data sets.

Larval $H$. aduncum are commonly found in varying stages of degeneration, and probably survive for approximately 1 year only. In addition, their smaller size (7-21 $\mathrm{mm}$ long compared to 19-32 $\mathrm{mm}$ for $A$. simplex) and occurrence among the pyloric caeca, make them difficult to find macroscopically. These factors combine to give this species less potential than $A$. simplex as a natural tag for adult herring.

\section{Terranova sp.}

Four specimens were found which were identified as third stage larvae of Terranova sp.; one in a commercial sample from Rhode Island during the winter of 1982, and three from a research cruise south of Cape Cod in the same winter. This is the first reported occurrence of Terranova in herring. Prevalence in samples south of Cape Cod was $0.3 \%$. It was not found in samples from the same study areas in 1983, nor was it found in any other area. Due to its rare occurrence and uncertain specific identify, this species was not of value as a biological tag.

Third stage larvae may be distinguished by the following criteria: broad, blunt head with anterior boring tooth (Fig. 4A), anterio-ventral excretory pore, ventral excretory duct which expands to a ribbon shaped excretory gland in the left ventral quadrant posterior to nerve ring, excretory gland nucleus at level of the posterior part of the ventriculus (in our specimens the oesophagus was folded) (Fig. 4B), elongate ventriculus with a straight junction with the intestine, intestinal caecum exceeding the length of the ventriculus and attached to the right lateral cord by a ligament (Fig. 4C), tail with mucron (Fig. 4D), one distinct tranverse cuticular stria on body just anterior to anus. All four specimens were distorted and the preventriculus was coiled or compressed. It is not known if this was due to stunted growth or damage from freezing.

\section{Larval cestodes}

Highest prevalences of larval cestodes were found south of Cape Cod and on Jeffreys Ledge in the autumn of 1981 (Table 1) but were lower everywhere than those reported in the 1950's by Sindermann (1957). None were found from eastern Maine samples in the autumn of 1981 but were present there in the autumn of 1982. Occurrence in samples collected off the Canadian coast was sporadic. Samples from the Bay of Fundy in summer 1981 and Southwest Nova Scotia in summer 1983 had prevalences of 2.0 and $2.5 \%$. Spawning fish sampled from Southwest Nova Scotia in the autumn of 1982 had a prevalence of $0.7 \%$. 


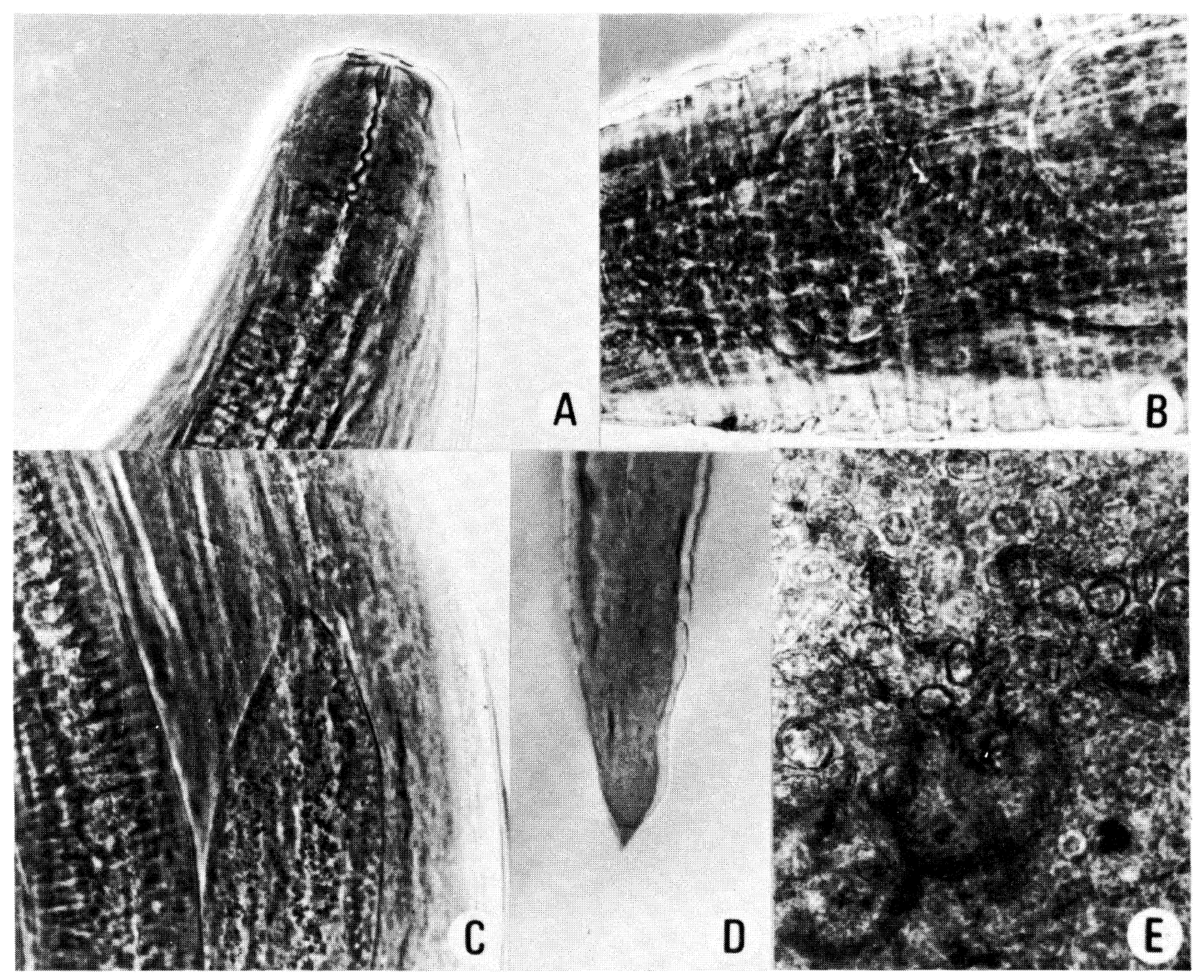

Fig. 4. Diagnostic features of third-stage Terranova sp. larva: (A) broad blunt head $(\times 225$, phase contrast); (B) compressed and coiled, damaged preventriculus ( $\times 225$, phase contrast); (C) ligament attaching intestinal caecum to body wall ( $\times 225$, phase contrast); and (D) broad-based mucron at tail $(\times 400$, bright-field). The unidentified larval cestode $(E)$ has round calcareous corpuscles and tentacles with rows of hooks $(\times 255$, phase contrast)

Spawning fish on Jeffreys Ledge that same year had a prevalence only slightly higher $(0.9 \%)$. Although distribution is not discontinuous, fish taken off the Canadian coast appear less likely to be infected.

Larval cestodes from the U.S. part of the study could not be positively identified due to the samples being frozen before examination. In the Canadian part of the study, some samples were examined fresh and cestodes could be identified as Grillotia erinaceus (van Beneden, 1858) and Lacistorhynchus tenuis (van Beneden, 1858; Pinpner, 1913), another tetrarhynchan plerocercoid. The larval $G$. erinaceus were found encysted in the body cavity on the surface of the stomach, pyloric caeca, and intestine. In all specimens the scolex was inverted, highly contorted, and the overall shape was oval and dorso-ventrally flattened. Descriptive material can be found in Schmidt (1986). Encysted trypanorhynch cestodes, found in the U.S. part of the study and not identified, showed round calcareous corpuscles and tentacles with rows of hooks (Fig. 4E).

\section{Discussion}

An earlier study by Boyar and Perkins (MS 1971) presented data on larval nematode infections of herring between 1962 and 1969 in four areas: Georges Bank, western Gulf of Maine, eastern Gulf of Maine and Nova Scotia. The larval nematodes were not identified to species and were all presumed to be Anisakis. The present study gave results similar to those of Boyar and Perkins (MS 1971) where prevalence increased with age and fish caught off Nova Scotia consistently showed higher infections than those from other areas. This clearly indicatrs that intermixing between populations was limited. Differences between the 1962-69 data and present data include: Georges Bank samples 
could no longer be obtained due to stock collapse; eastern Gulf of Maine no longer showed higher prevalences than western Gulf of Maine; incidences in general were lower than in earlier years; and the difference between samples from Nova Scotia and from other areas was greater in this study than in the earlier work.

Stobo (MS 1982) reported that some of the herring tagged off Southwest Nova Scotia in 1974 and 1977 moved west and south in the winter with tags recovered from the fishery in Massachusetts Bay and from south of Cape Cod. Fish from the 1974 tagging were primarily in prespawning condition, stage $V$, while in 1977 stage VI, or actually spawning fish, predominated. A greater proportion of the tagged fish moved west in the 1974 study than in the 1977 study. This led Stobo (MS 1982) to conclude: "The differing results of the two studies, in conjunction with the information on stage of sexual maturity, has led to the hypothesis that during the feeding and prespawning period, the Bay of Fundy has a large admixture of Gulf of Maine and Scotian Shelf stocks. As the fish near the 'ripe and running' sexual maturity stage they begin to segregate. The Gulf of Maine herring move westward towards their spawning grounds. The Subdivision $4 \mathrm{WX}$ herring stay in the Southwest Nova Scotia area to spawn, and subsequently move eastward to overwinter. The fact that a proportion of the fish tagged in 1977 still moved westward may mean that Gulf of Maine fish were still in the area at time of spawning for Southwest Nova Scotia fish, and further illustrates the complexity of the stock interrelationships." In contrast to this theory, the United States Herring Management Plan (NEFMC, 1978) assumed that up to $50 \%$ of the Southwest Nova Scotia stock overwintered in U.S. waters. Similarly, the New England States Regional Herring Management Plan (Anon., 1983) indicated 40\%.

The present study of herring parasites supports Stobo's (MS 1982) theory. Southwest Nova Scotia spawners are characterized by a high prevalence of $A$. simplex (46\%, see Table 3$)$. Jeffreys Ledge spawners have a low prevalence (16\%). Prevalences in all samples from the Maine and South of Cape Cod areas were similar to that for Jeffreys Ledge spawners (when differences in size and age are taken into account) even though these were collected mainly in autumn and winter. If a large proportion of the Southwest Nova Scotia spawning stock (which is the larger of the two) overwintered to the south, winter prevalence should be higher than that of Jeffreys Ledge spawners.

Tagging data indicated that herring move along the Maine coast and into the Bay of Fundy (mainly on the New Brunswick side) during summer and autumn. A. simplex prevalence in the Bay of Fundy was highest in winter $(35 \%)$, and the lower prevalence at other times of the year is consistent with a summer migration of fish with low infections up the Maine coast. Parasite prevalence in Southwest Nova Scotia samples is about the same as that characterizing Southwest Nova Scotia spawners (46\%) when differences in size and age are considered, and the data give little indication of a seasonal influx of fish with low infections. However, sample sizes were small and may have been inadequate to detect such an influx.

Tagging experiments and use of parasites as indicators of movement are both subject to a number of drawbacks (Sindermann, 1979). However, both methods of studying herring movements gain substantially in value and reliability when used together. The low cost information provided by certain herring parasites can be used to support results of tagging experiments which are costly, subject to low percentages of returns, and may be beset by numerous technical problems (difficulty in tagging from purse seiners, the differential mortality of tagged individuals, temperatures too cold, dependence on commercial fishery). Conversely, returns from tagging experiments can be used to support or refute proposed patterns of herring movement based on parasite indicators.

Routine examination of $A$. simplex could be incorporated easily into existing biological monitoring programs. A yearly baseline study of spawning fish in each area (Jeffreys Ledge and Southwest Nova Scotia) would establish current prevalences. This knowledge could then be used when examining samples from fisheries at other than spawning times to determine possible associations with the two major spawning stocks. Such information would be useful for management purposes, both for determining if and when the Southwest Nova Scotia stock is present in other areas, and if and when the Jeffreys Ledge stock is present in summer feeding concentrations in Canadian waters.

\section{Acknowledgements}

We thank M. D. B. Burt of the University of New Brunswick and T. D. Iles, Department of Fisheries and Oceans, St. Andrews, N. B. for their generous support of the Canadian research. Also, Earl J. Lewis of National Marine Fisheries Service, Oxford, Maryland, and Mark E. Galasso of Environmental Concerns, Inc., St. Michaels, Maryland, for assistance in identifying specimens from the collection; Michelle Cox, National Marine Fisheries Service, Sandy Hook, New Jersey, and James Rollins, Bigelow Laboratory, Boothbay Harbor, Maine, for illustrations; and at the Maine Department of Marine Resources, Sally Sherman for keypunching, Margaret Hunter for computer processing, and Pamela Mancuso for several typings of the manuscript. 


\section{References}

ANON. 1983. Interstate sea herring management plan of Maine, New Hampshire, Massachusetts, and Rhode Island. $106 \mathrm{p}$.

ANTHONY, V. C., and H. C. BOYAR. 1968. Comparison of meristic characters of adult Atlantic herring from the Gulf of Maine and adjacent waters. ICNAF Res. Bull., 5: 91-98.

BERLAND, B. 1961. Nernatodes from Norwegian marine fishes. Sarsia, 2: 1-50.

BEVERLEY-BURTON, M., and J. H. C. PIPPY. 1977. Morphometric variations among larval Anisakis simplex (Nematoda: Ascaridoidea) from fishes of the North Atlantic and their use as biological indicators of host stocks. Environ. Biol. Fish., 2: 309-314.

BOYAR, H. C. MS 1967. Age, length and maturity of adult herring in Subarea 4 and 5, 1966. ICNAF Res. Doc., No. 24, Serial No. 1802, 5 p.

BOYAR, H. C., and F. E. PERKINS. MS 1971. The occurrence of a larval nematode (Anisakis sp.) in adult herring from ICNAF Subareas 4 and 5, 1962-1969. ICNAF Res. Doc. No. 99, Serial No. 2576, 2 p.

CHENG, T. C. 1976. The natural history of anisakiasis in animals. J. Milk Tech., 39: 32-46.

CRAWFORD, R. H. MS 1980. A biological analysis of herring from the Atlantic coast of Nova Scotia and eastern Northumberland strait. Nova Scotia Dept. of Fisheries, Manuscript and Technical Report Series, Project Report No. 80-03, $45 \mathrm{p}$.

GIBSON, D. I. 1983. The systematics of ascaridoid nematodes: a current assessment: In: Concepts in nematode systematics (p. 321-338), A. R. Stone, H. M. Platt and L. F. Khalik (ed.), Systematics Assoc. Spec. Publ. No. 22, Academic Press, New York, and London.

HISLOP, J. R. G., and K. MacKENZIE. 1976. Population studies of the whiting Merlangius merlangus (L.) of the northern North Sea. ICES J. Cons., 37: 98-110.

ICNAF. 1964. Report of standing committee on research and statistics. App. 1. Report of ad hoc group on herring and other pelagic fish. ICNAF Redbook, 1964(1): 23-30.

KULKA, D. W., S. COREY, and T. D. ILES. 1982. Community structure biomass of euphausiids in the Bay of Fundy. Can. J. Fish. Aquat. Sci., 39: 326-334.

LUBIENIECKI, B. 1973. Note on the occurrence of larval Anisakis in adult herring and mackerel from Long Island to Chesapeake Bay. ICNAF Res. Bull. 10: 79-81.

LUBIENIECKI, B. 1977. The plerocerus of Grillotia erinaceus as a biological tag for haddock Melanogrammus aeglefinus in the North Sea and northeast Atlantic. J. Fish. Biol., 11: 555-565.

MacKENZIE, K. MS 1974. The use of parasites in tracing herring recruitment migrations. ICES C. M. Doc., No. $\mathrm{H}: 31,4 \mathrm{p}$.

MacKENZIE, K., and C. JOHNSTON. MS 1976. Recruitment of the Minch herring population, as determined by the use of parasites as biological tags and a new meristic character. ICES C.M. Doc., No. H:34, 10 p.

MARGOLIS, L. 1963. Parasites as indicators of the geographic origin of sockeye salmon, Oncorhynchus nerka (Walbaum), occurring in the North Pacific Ocean and adjacent seas. Bull. INPFC, 11: 101-156.

McGLADDERY, S. E. MS 1984. Studies of the parasite fauna of Atlantic herring (Clupea harengus L.) from the north- western Atlantic Ocean. Ph.D. Thesis, Univ. of New Brunswick, Fredericton, N. B., 286 p.

McGLADDERY, S. E., and M. D. B. BURT. 1985. Potential of parasites for use as biological indicators of migration, feeding, and spawning behaviour of northwestern Atlantic herring (Clupea harengus). Can. J. Fish. Aquat. Sci., 42: 1957-1968

NEFMC. 1978. Final environmental impact statement and fisheries management plan for the Atlantic herring fishery of the Northwest Atlantic, August 1978. New England Fishery Management Council, $371 \mathrm{p}$.

ODENSE, P. H., and T. M. ALLEN. 1971. A biochemical comparison of some Atlantic herring populations. ICES Rapp. Proc.-Verb., 161: 26.

OSHIMA, T. 1972. Anisakis and anisakiasis in Japan and adjacent areas. In: Progress of medical parasitology in Japan, Vol. 4 (p. 301-393), K. Morishuta (ed.), Meguro Parasit. Mus., Tokyo, Japan.

PARSONS, L. S. 1975. Morphometric variation in Atlantic herring from Newfoundland and adjacent waters. ICNAF Res. Bull., 11: 73-92.

PARSONS, L. S., and V. M. HODDER. 1971. Variation in the incidence of larval nematodes in herring from Canadian Atlantic waters. ICNAF Res. Bull. 8: 5-14.

PIPPY, J. H. C., and P. Van BANNING. 1975. Identification of Anisakis larvae as Anisakis simplex (Rudolphi, 1809, det. Krabb 1878) (Nematoda: Ascaridata). J. Fish. Res. Board Can. 32: 29-32.

RIDGWAY, G. J., R. D. LEWIS, and S. W. SHERBURNE. 1971. Serological and biochemical studies of herring populations in the Gulf of Maine. ICES Rapp. Proc.-Verb., 161: 21-25.

SCHMIDT, G. D. 1986. Handbook of tapeworm identification. CRC Press Inc., Boca Raton, Fla., 675 p.

SHERMAN, K., and J. P. WISE. 1961. Incidence of the cod parasite Lernaeocera brachialis L. in the New England area, and its possible use as an indicator of cod populations. Limnol. Oceanogr., 6: 61-67.

SINDERMANN, C. J. 1957. Diseases of fishes of the western North Atlantic. V. Parasites as indicators of herring movements. Res. Bull. Dept. Sea Fish. Maine, 27: $30 \mathrm{p}$.

SINDERMANN, C. J. 1961. Parasite tags for marine fish. J. Wildlife Manag. 25: 41-47.

SINDERMANN, C. J. 1979. Status of Northwest Atlantic herring stocks of concern to the United States. U.S. Nat. Mar. Fish. Serv., Tech. Rep., ;23: 449 p.

SMITH, J. W. 1983. Larval Anisakis simplex (Rudolphi, 1809, det. Krabbe, 1878) and larval Hysterothylacium sp. (Nematoda: Ascaridoidea) in euphausiids (Crustacea: Malacostraca) in the North-East Atlantic and northern North Sea. J. Helminth., 57: 161-177.

SMITH, J. W., and R. WOOTTEN. 1978. Anisakis and anisakiasis. Adv. Parasitol., 16: 93-163.

STOBO, W. T. MS 1976. Movements of herring tagged in the Bay of Fundy - update. ICNAF Res. Doc., No. 48, Serial No. $3834,16 \mathrm{p}$.

STOBO, W. T. MS 1982. Tagging studies on Scotian Shelf herring. NAFO SCR Doc., No. 108, Serial No. N617, 16 p.

STUNKARD, H. W., and F. E. LUX. 1965. A microsporidian infection of the digestive tract of the winter flounder, Pseudopleuronectes americanus. Biol. Bull., 129: 371387.

THIEL, P. H. Van. 1966. The final hosts of the herring worm 
Anisakis marina. Trop. Geogr. Med., 18: 310-328. Van BANNING, P., J. F. DeVEEN, and P. I. Van LEEUWEN. MS

1978. The myxosporidan parasite Myxobolus aeglefini Auerbach, 1906, and its uses as a parasitological tag for plaice of the eastern North Sea. ICES C.M. Doc., No. $\mathrm{G}: 48,8 \mathrm{p}$.

VIK, R. 1964. Penetration of stomach wall by Anisakis-type larvae in porpoises. Can. J. Zool., 42: 573. 
